\title{
OCCURRENCE OF AGGREGATIBACTER ACTINOMYCETEMCOMITANS IN BRAZILIAN INDIANS FROM UMUTINA RESERVATION, MATO GROSSO, BRAZIL
}

\author{
Evanice Menezes Marçal VIEIRA ${ }^{1}$, Suzane A. RASLAN ${ }^{2}$, Thais Cristina WAHASUGUI ${ }^{3}$, Mario Julio AVILA-CAMPOS ${ }^{4}$, \\ Valdecir MARVULLE ${ }^{5}$, Elerson GAETTI-JARDIM JÚNIOR
}

\begin{abstract}
1- MSc, Graduate student, Department of Pathology and Propedeutics, Araçatuba Dental School, São Paulo State University, Araçatuba, SP, Brazil.
2- MSc, Assistant Professor, Department of Dentistry, University of Cuiabá, Cuiabá, MT, Brazil.

3- Undergraduate student, Department of Microbiology, Institute of Biomedical Sciences, University of São Paulo, São Paulo, SP, Brazil.

4- PhD, Full Professor, Department of Microbiology, Institute of Biomedical Sciences, University of São Paulo, São Paulo, SP, Brazil.

5- PhD, Full Professor, Center of Mathematics, Computation and Cognition, Federal University of ABC, Santo André, SP, Brazil.

6- PhD, Associate Professor, Department of Pathology and Propedeutics, Araçatuba Dental School, São Paulo State University, Araçatuba, SP, Brazil.

Corresponding address: Dr. Elerson Gaetti Jardim Júnio - Faculdade de Odontologia de Araçatuba - UNESP - Rua José Bonifácio, 1193 - 16015-050 - Araçatuba, SP - Brazil - Phone/Fax: +55-18-3636-2797/3636-3200 - e-mail: egaettij@foa.unesp.br
\end{abstract}

Received: September 9, 2008 - Accepted: January 10, 2009

\begin{abstract}
A

ggregatibacter actinomycetemcomitans is associated with periodontal disease, especially localized aggressive periodontitis, produces a potent leukotoxin and its distribution is influenced by ethnic characteristics of the population. Objective: Using culture and polymerase chain reaction (PCR) techniques, this study evaluated the occurrence of this microorganism and the distribution of leukotoxic strains isolated from Indians belonging to the Umutima Reservation, Mato Grosso, Brazil. Material and Methods: Fortyeight native Brazilians with gingivitis and 38 with chronic periodontitis, belonging to Umutina, Paresi, Bororo, Bakairi, Kayabi, Irantxe, Nambikwara and Terena ethnicities, were studied. Subgingival, supragingival and saliva samples of each patient were collected and transferred to VMGA III medium and to ultra pure Milli Q water. Bacteria were grown on TSBV agar and incubated in anaerobiosis $\left(90 \% \mathrm{~N}_{2}+10 \% \mathrm{CO}_{2}\right)$ at $37^{\circ} \mathrm{C}$ for $72 \mathrm{~h}$. The presence of the ltx promoter was determined by PCR, and a $530 \mathrm{bp}$ deletion in the promoter was evaluated by using specific primers. Results: A. actinomycetemcomitans was isolated from $8.33 \%$ of saliva, supragingival and subgingival samples from patients with gingivitis and from $18.42 \%$ of saliva and supragingival biofilm, and $26.32 \%$ subgingival biofilm from patients with chronic periodontitis. By PCR, the bacterial DNA was detected in $8.33 \%$ of saliva, supragingival and subgingival biofilms from patients with gingivitis and from $23.68 \%$ of saliva, $28.95 \%$ supragingival biofilm and $34.21 \%$ subgingival biofilm from patients with periodontitis. All strains were grouped as non-JP2 clones based on the absence of deletion in the leukotoxin promoter. Differences among the microbial and clinical parameters in patients were analyzed by using the Mann-Whitney, Chi-square or Fisher's exact tests. Conclusions: The present results suggest that A. actinomycetemcomitans can be related to the attachment loss in this population, but the presence of minimally leukotoxic strains, as well as its role in the pathogenesis of the periodontitis in these native Brazilians need to be further investigated.
\end{abstract}

Key words: Periodontitis. Gingivitis. Bacteria. Native Americans.

\section{INTRODUCTION}

Aggregatibacter actinomycetemcomitans is a gramnegative coccobacillus related to the aggressive periodontal disease and it has been associated to several infectious diseases, such as, septic endocarditis, brain and lung abscesses, osteomyelitis, subcutaneous abscesses, cardiovascular diseases ${ }^{6,23}$ and chronic periodontal diseases $^{9,28,30}$.

The virulence of $A$. actinomycetemcomitans is still not well understood, but it is able to produce a heat-labile leukotoxin, which belongs to the repeat-in-toxin (RTX) family. The gene ltxA encodes a structural leukotoxin and genes ltx $\mathrm{B}$ and lt $x \mathrm{D}$ encode proteins required for its secretion. Gene $\operatorname{lt} x \mathrm{C}$ encodes an acyltransferase that is responsible for the modification of proto-toxin to the active toxin $^{16}$. Moreover, the leukotoxin production has been associated to evasion against the defense cells of the periodontal tissues $^{6,13}$.

The ltx operon harbors the genetic determinants to 
synthesis, activation, and secretion that is present in all $A$. actinomycetemcomitans strains ${ }^{12}$, but the toxin expression levels can be different among clones ${ }^{9}$. Moreover, it has been observed that the presence of a $530 \mathrm{bp}$ deletion in the promoter region is related to the increased leukotoxin expression $^{9,12}$. The occurrence of highly leukotoxic strains of $A$. actinomycetemcomitans strains has shown variations among ethnic groups ${ }^{9,17}$, showing high frequencies in certain Arabs and Africans and their descendents ${ }^{9}$ and being uncommon in Latin-Americans $\mathbf{s}^{1,10,15}$, Asians ${ }^{17}$ or Europeans ${ }^{10}$. On the other hand, there is a need to confirm this statement in Brazilian populations, which display peculiarities, such as racial miscegenation and cultural aspects ${ }^{24}$.

However, some native Brazilian groups remain in partial or total physical or cultural isolation. To the best of our knowledge, this study is the first report the presence of oral leukotoxic $A$. actinomycetemcomitans in a native population (Umutima reservation) of Indians from Umutina, Paresi, Bororo, Bakairi, Kayabi, Irantxe, Nambikwara and Terena ethnicities. They are descendents from small native groups that survived a severe depopulation in the 20th century due to contacts with non-Indian populations. In addition, the endogamy is common in these native Brazilians, leading to a very homogeneous population, what may affect their susceptibilities to several infectious pathologies.

In this study, the occurrence of $A$. actinomycetemcomitans strains in native Brazilian groups belonging to the Umutina Indian Reservation, Mato Grosso, MT, Brazil, was evaluated by using culture and PCR method, as well as, the distribution of minimally or highly leukotoxic strains was determined.

\section{MATERIAL AND METHODS}

\section{Patients and sample collection}

A total of 86 patients aged from 18 to 96 years old (31.5 \pm 19.9 years) from Umutina, Paresi, Bororo, Bakairi, Kayabi, Irantxe, Nambikwara and Terena ethnic groups of the Umutima Indian Reservation, MT, Brazil, was included in this study. Forty-eight Indians with gingivitis displaying crevice depth $=3 \mathrm{~mm}$ and at least $20 \%$ of gingival sites with bleeding on probing, and 38 patients with periodontitis showing at least three periodontal sites with pocket depth $=$ $5 \mathrm{~mm}$, attachment loss and bleeding on probing were selected. Patients with periodontitis displayed an average plaque index $(\mathrm{PI})^{25}$ of 2.2, an average of gingival index $(\mathrm{GI})^{18}$ of 1.8, and an average periodontal pocket depth (PPD) of $5.8 \mathrm{~mm}$ ( 5 to $9 \mathrm{~mm}$ ). Patients with gingivitis displayed an average $\mathrm{PI}=2.0$, an average $\mathrm{GI}=1.6$ and an average PPD $=2.8 \mathrm{~mm}$ (1 to $3 \mathrm{~mm})$. None of selected individuals had received antibiotics for at least 6 months prior to the sample collection or had been submitted to dental treatment ${ }^{5}$. All the patients received full information about the study and gave a signed authorization.

This study was approved by the Ethics Committee of Araçatuba Dental School, São Paulo State University (FOAUNESP 2006-01417 CEP) and by the Ethics Committee of the Public Health School of Mato Grosso (021/07 CEP/SES-
MT). Additionally, this study was also approved by the Community Leaders and by the Members of the Health Council of the Reservation, Ethics Committee of the National Indian Foundation-FUNAI, and Ethics Committee of the National Health Foundation-FUNASA.

Clinical samples were taken from three most diseased sites in each patient. Supragingival samples were obtained by scaling and transferred to VMGA III medium ${ }^{21}$ and ultra pure Milli Q water. Subgingival samples were obtained by using two sterile paper points (Dentsply Indústria e Comércio Ltda., Petrópolis, RJ, Brazil) inserted into the apical region of periodontal pockets or gingival crevices for $60 \mathrm{~s}$ and transported in VMGA III medium ${ }^{21}$ and ultra pure Milli Q water. Saliva was collected by using Salivette devices (Aktiengesellsschaft, Nümbrecht, Germany), which were centrifuged at 5,000x g for $2 \mathrm{~min}$ and the saliva was immediately diluted in VMG I and plated on selective and non-selective culture media.

Samples were plated onto a selective TSBV $\operatorname{agar}^{27}$ for isolation and CFU determination of $A$. actinomycetemcomitans and onto Brucella agar enriched with $5 \%$ horse blood and supplemented with $5 \mu \mathrm{g} / \mathrm{mL}$ hemin and $1 \mu \mathrm{g} / \mathrm{mL}$ menadione for total CFU determination. Plates were incubated in anaerobiosis $\left(90 \% \mathrm{~N}_{2}+10 \% \mathrm{CO}_{2}\right)$ at $37^{\circ} \mathrm{C}$ during $72 \mathrm{~h}$ and 14 days, respectively. Characteristic colonies of $A$. actinomycetemcomitans on TSBV agar were cultivated and identified by biochemical methods ${ }^{26}$.

\section{Bacterial DNA Amplification by PCR assay}

\section{DNA extraction}

Bacterial DNA was obtained from each sample collected in sterile ultra-pure water by using a QIAamp DNA Mini Kit (Qiagen, Hilden, Germany). The DNA concentration was determined at $\mathrm{A}_{260} \mathrm{~nm}$ (spectrophotometer DU-640, Beckman Instruments, Richmond, CA, USA).

For A. actinomycetemcomitans detection in clinical samples a specific primer pair was used, LKT-F: 5' - GGA ATT CCT ATT TAT TGC GAAACAATT TGA TC -3' and LKT-R: 5'- GGA ATT CCT GAA ATT AAG CTG GTA ATC -3 ' as previously described by Kraig, et al. ${ }^{14}$. Amplifications were performed in volumes of $25 \mu \mathrm{L}$ containing $1 \mathrm{X} \mathrm{PCR} / \mathrm{Mg}^{++}$buffer (Boehring Mannheim, Indianapolis, IN, USA), $0.2 \mathrm{mM}$ of each dNTP (Pharmacia Biotech, Piscataway, NJ, USA), 0.5 U Taq DNA polymerase (Invitrogen do Brasil, São Paulo, SP, Brazil), $0.4 \mu \mathrm{M}$ of each primer pair (Invitrogen) and $10 \mathrm{ng}$ of template. Amplification reactions were carried out in a Thermal Cycler (Perkin Elmer, GeneAmp PCR System 9700, Norwalk, CT, USA) programmed at $94^{\circ} \mathrm{C}$ for $5 \mathrm{~min}$ ), followed by 35 cycles at $94^{\circ} \mathrm{C}$ for $30 \mathrm{~s} ; 55^{\circ} \mathrm{C}$ for $30 \mathrm{~s} ; 72^{\circ} \mathrm{C}$ for $1 \mathrm{~min}$; then $72^{\circ} \mathrm{C}$ for 5 min to allow the DNA extension.

PCR products were analyzed by electrophoresis in 1\% agarose gel in $1 \mathrm{X}$ TBE (1 M Tris, $0.9 \mathrm{M}$ boric acid, $0.01 \mathrm{M}$ EDTA, pH 8.4) buffer (Gibco BRL, Life Technologies, Ltd., Bethesda, MD, USA), stained with $0.5 \mathrm{mg} / \mathrm{mL}$ ethidium bromide and photographed on a UV light transilluminator (Kodak Digital Science, Electrophoresis Documentation 
Analysis System 120, Eastman Kodak Co., Rochester, NY, USA).

In $10 \%$ of the positive samples, amplicons were purified from gel by using a QIAquick Gel Extraction Kit (Qiagen Inc., Hilden, Germany) and processed for sequencing. The PCR products were cloned using a cloning kit (T/A PCR Script Amp SK, Stratagene, La Jolla, CA, USA) and transformed into E. coli XL1-Blue. Plasmid DNA was purified on a QIA-prep Spin Column (Qiagen Inc.) and sequenced. DNA sequencing was performed on an automated DNA sequencer (ABI model 373S; Applied Biosystems, Foster City, CA, USA) using a terminator cycle sequencing kit (PRISM Ready Reaction Dye-Deoxy; Applied Biosystems). The sequencing reaction products were purified by using spin columns (Centri-Sep, Princeton Separations, Inc., Princeton, NJ, USA). DNA sequences were aligned, edited, and consensus sequences were determined. Sequences were submitted using BLAST to search for GenBank (GenBank, National Center for Biotechnology Information, Bethesda, MD, USA) with sequence similarities. The products evidenced a homology of $98-99 \%$ with the sequences of $A$. actinomycetemcomitans.

Detection of the $530 \mathrm{bp}$ deletion in the leukotoxin promoter of $A$. actinomycetemcomitans

The deletion detection in 52 isolates of $A$. actinomycetemcomitans was performed by using a PRO primer pair (F: 5'- GTA ATG AAA ATT GCC GCT TT 3'and R: 5'- CCA TAT TAA ATC TCC TTG TTA A -3'), producing a $1,075 \mathrm{bp}$ amplicon (minimally leukotoxic) or a 545 bp amplicon (highly leukotoxic), as described by Mombelli, et al. ${ }^{22}$. The amplification reactions were carried out using the same conditions described above.

\section{Statistical Analysis}

Statistical analyses were performed by using the software Statistical Package for the Social Sciences v. 13 (SPSS Inc., Chicago, IL, USA). Differences among clinical and microbiological parameters were evaluated using the MannWhitney, Chi-square or Fisher's exact tests. Any difference of $p<0.05$ was considered statistically significant.

\section{RESULTS}

All the individuals from the Umutina Indian Reservation displayed some inflammation in the gingival tissues. Moreover, no subject showed aggressive periodontitis.

From subgingival biofilm, A. actinomycetemcomitans was cultivated from $10(26.32 \%)$ periodontitis and $4(8.33 \%)$ patients with gingivitis. By PCR, this bacterium was detected in $34.21 \%$ of the periodontitis and in $8.33 \%$ of the gingivitis samples (Figure 1). A. actinomycetemcomitans was also isolated from $8.33 \%$ of saliva samples and supragingival samples from patients with gingivitis and from $18.42 \%$ of saliva and supragingival biofilm from patients with chronic periodontitis. By PCR, the bacterial DNA was detected in $8.33 \%$ of saliva, supragingival and subgingival biofilms from patients with and in $23.68 \%$ of saliva, $28.95 \%$ supragingival biofilm from patients with periodontitis.

A. actinomycetemcomitans represented $0.88 \%$ of the cultivable microbiota of the periodontitis and $0.66 \%$ of the patients with gingivitis (Figure 2). It was demonstrated an approximately $1.0 \mathrm{~kb}$ ltx promoter region amplicon in all 52 isolates indicating that none of them belonged to the JP2 clone.

The occurrence of this microorganism in saliva and supra

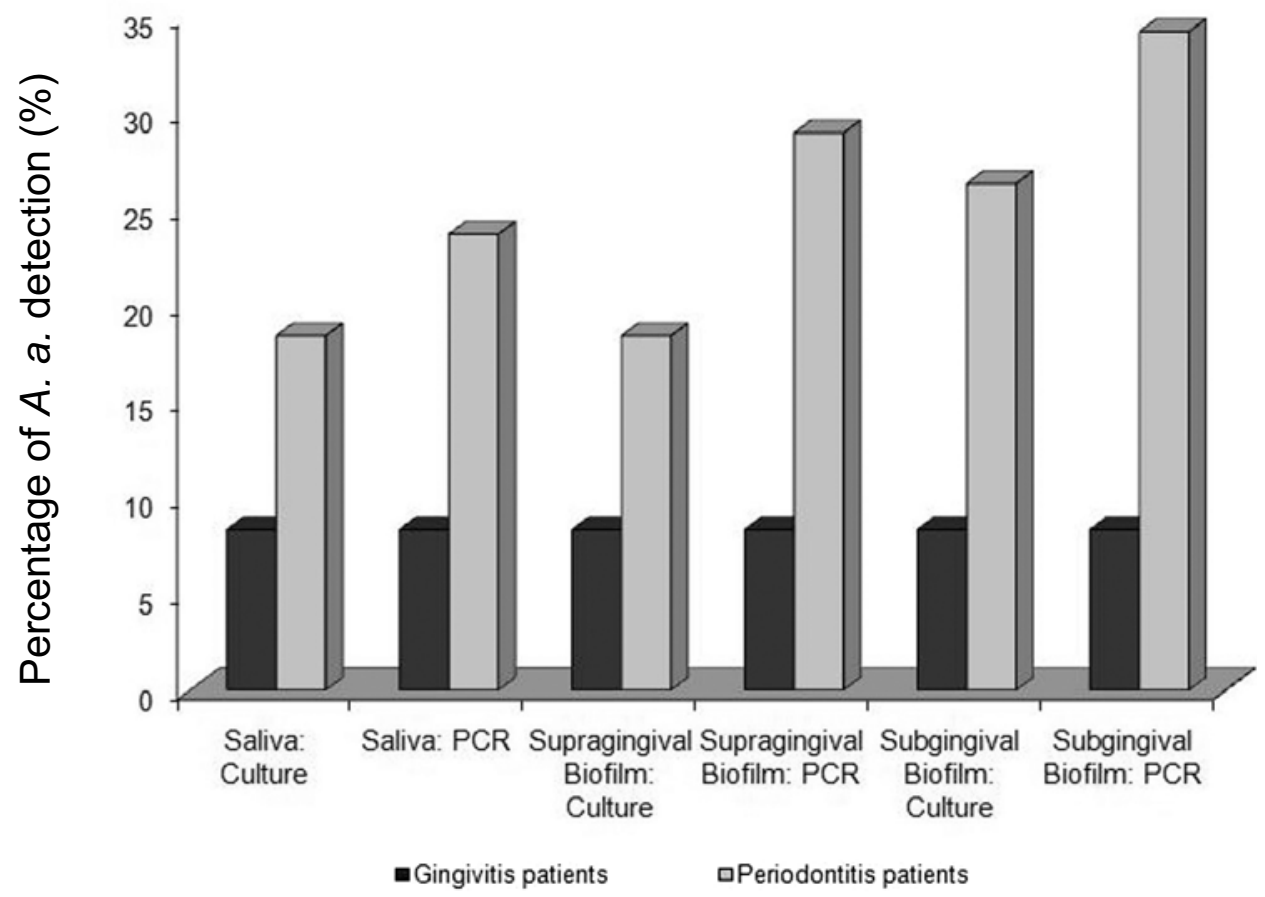

FIGURE 1- Detection of Aggregatibacter actinomycetemcomitans in saliva, supragingival biofilm, and subgingival biofilm from Brazilian Indians by culture and PCR 


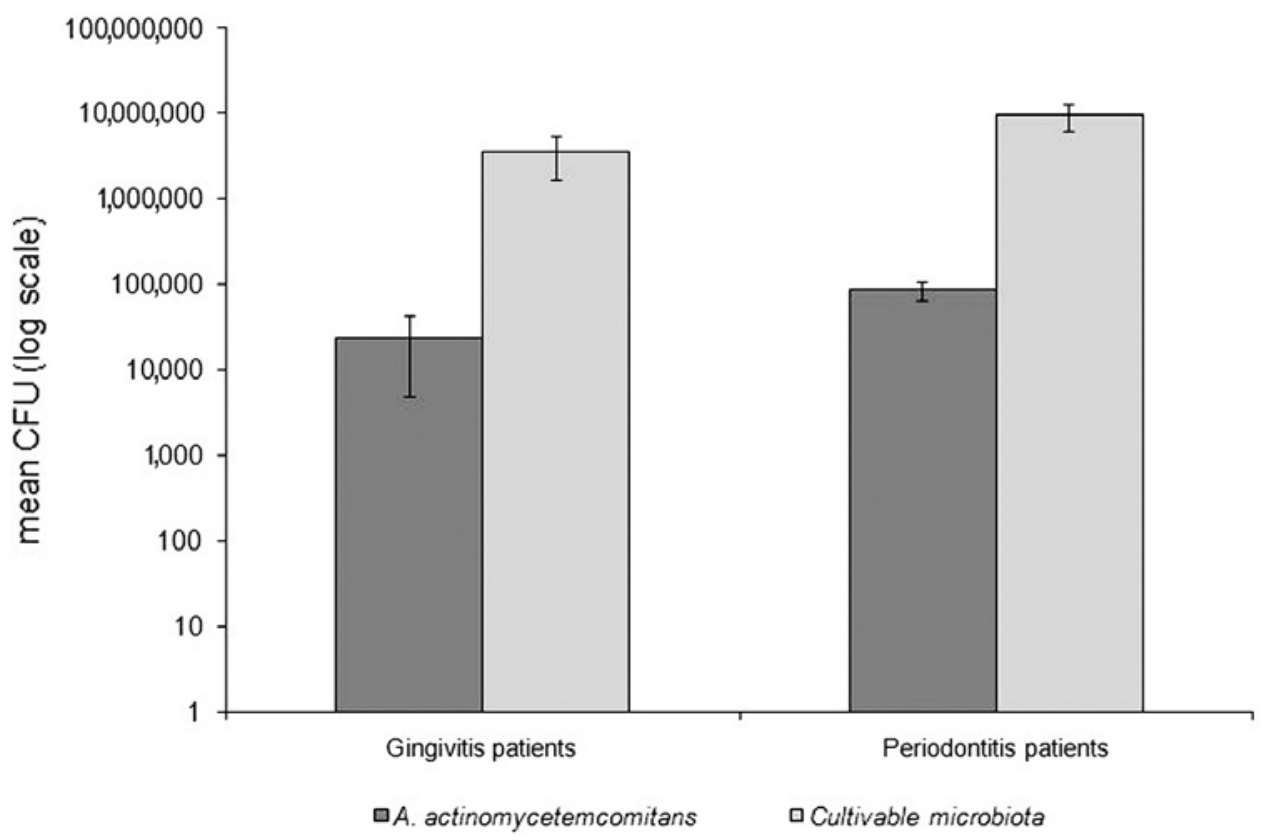

FIGURE 2- Occurrence of Aggregatibacter actinomycetemcomitans in subgingival biofilm from Brazilian Indians evaluated by culture

gingival biofilm was associated with the presence of this bacterium in subgingival samples (Chi-square test, $\mathrm{p}<0.001)$. Additionally, A. actinomycetemcomitans was associated with the poor hygiene (Mann-Whitney test; $\mathrm{p}=0.006)$, bleeding on probing (Mann-Whitney test, $\mathrm{p}=0.042$ ), young subjects (age $<30$ years, Mann-Whitney test, $\mathrm{p}=0.041$ ), periodontal breakdown (Chi-square test, $\mathrm{p}=0.009$ ), low frequency of tooth brushing (Chi-square test, $\mathrm{p}=0.034$ ) and dental floss usage (Chi-square test, $\mathrm{p}=0.0039$ )

\section{DISCUSSION}

The present investigation assessed the occurrence of $A$. actinomycetemcomitans in a native Brazilian population presenting a high degree of social isolation. The presence of gingivitis or periodontitis in these individuals was associated with their poor oral hygiene. However, traditional native habits, such as chewing some kinds of barks to improve the oral health, were followed. It is often assumed that the gingival and periodontal microbiota in individuals from a geographic location may be extrapolated to other locations. Nevertheless, this is a misconception, since studies have suggested a great microbial heterogeneity in the human subgingival microbiota ${ }^{8}$, particularly when native populations from South America are involved, due to their ethnic, cultural, social and dietary particularities ${ }^{11}$.

In this study, $A$. actinomycetemcomitans was isolated and identified from subgingival biofilm from $26.32 \%$ and $8.33 \%$ of patients with periodontitis and gingivitis, respectively. On the other hand, by using PCR, the microbial detection was observed in $34.21 \%$ of the periodontitis, and in $8.33 \%$ of the patients with gingivitis, respectively. Moreover, studies have shown that the occurrence of $A$. actinomycetemcomitans in $12 \%$ to $80 \%$ from non-Indian individuals with chronic periodontitis ${ }^{1,5,7,10,30}$.

The isolation frequency of $A$. actinomycetemcomitans by culture and the detection by PCR was similar to that previously reported for Northwestern Europeans ${ }^{2}$, Colombians ${ }^{15}$, and native Brazilians of the Xingu Indian Park $^{11}$, but significantly lower than previously reported for Brazilian urban populations ${ }^{4,5}$. The occurrence of $A$. actinomycetemcomitans in other Latin-American populations has shown opposite results, while in Mexicans ${ }^{29}$ and Chileans ${ }^{19}$ this microorganism was observed in most of subgingival samples of patients with chronic periodontitis, in Colombians ${ }^{10,15}$ this pathogen is detected in nearly $20 \%$ of patients with chronic periodontitis.

Although the total microbial load in patients with periodontitis in comparison to patients with gingivitis was significantly higher, the $A$. actinomycetemcomitans population was enhanced in a higher extension than observed to the total of microbial population, as also described in literature $^{8,29}$. In the present study, A. actinomycetemcomitans represented almost $0.9 \%$ of the cultivable microbiota of the subgingival biofilm of patients with periodontitis and $0.7 \%$ of the patients with gingivitis (Figure 2) and this difference was statistically significant. This ability to survive and colonize periodontal pockets probably is related to its large scope of virulence factors that include proteolytic activity, capacity of modulate immune response, evasion of phagocytosis, ability to evade and/or damage the immune system and produce periodontal breakdown ${ }^{6}$.

Although grouped into an ethnic, social and racial single category, native Brazilians belong to more than 300 ethnic and linguistic affiliations, with strong differences in culture, habits and degree of exposition to non-Indian communities outside reservations. Although the first contacts with non- 
Indians happened in 20th century, the communities of the Umutina Indian Reservation localized on the Central Brazilian Highlands, near the geographical center of South America mainland, remain culturally and politically independent of the non-Indians populations.

It is likely that saliva, inanimate objects (toothbrushes) and direct mucosal contact are the transmission routes of periodontal bacteria, suggesting person-to-person transmission of these microorganisms. Then, the reduced contact with non-Indian communities may have prevented significant contacts with periodontal microbiota of the human populations who live in the borders of the Indian reservation. Thus, the features of Indian oral microbiota are probably associated to the ancestors' oral microbiota. In addition, the cultural and physical isolation of this population associated to a high frequency of endogamy, produced some particular traits, such as the high incidence of ankyloglossia (37.75\% of a population of almost 300 patients examined), suggesting a genetic characteristic in that population, since it is reported in $4.8 \%$ of non-native North Americans ${ }^{20}$.

Haubek, et al. ${ }^{9}$, have suggested that highly leukotoxic A. actinomycetemcomitans comprise a single clone frequently associated to African populations (JP2 clone). In Brazil, a multi-ethnic population with a strong racial mixture and predominance of Afro and Mediterranean Europeans descents are observed. Thus, the occurrence of different oral pathogens in subgingival biofilms may reflect this characteristic. Since natives of the Umutina Indian Reservation are descending from several almost extinct ethnic groups, which preserve their cultural, social, dietary and ethnic traditions, with rare racial-miscegenation, the scarce contact with non-Indians may collaborate to avoid a significant colonization by high leukotoxic strains of $A$. actinomycetemcomitans, which are more frequent in nonnative Brazilians ${ }^{24}$. This particularity is relevant since there are several evidences of intra-familial transmission of periodontal bacteria ${ }^{9}$, and Indians from the Umutina Indian Reservation living in a geographic area where the risk of acquiring this microorganism from non-Indians is reduced.

It has been suggested that the presence of highly leukotoxic strains play an important role in pathogenesis of the periodontal disease $\mathrm{e}^{9,12}$. Moreover, a strong correlation between the JP2 clone and periodontal breakdown has been observed particularly in adolescents displaying early bone loss $\mathrm{s}^{5,17}$. Populations harboring highly leukotoxic $A$. actinomycetemcomitans are 22.5 times more likely to develop localized aggressive periodontitis than subjects colonized by strains harboring full-length leukotoxin promoter region ${ }^{3}$. In Brazil, studies have showed that there are a strong correlation between highly leukotoxic $A$. actinomycetemcomitans and periodontitis ${ }^{5,24}$, but the results of the present study suggest that this association seem not to be true for Brazilian native Indians since none of them neither harbored highly leukotoxic JP2 clone nor displayed aggressive periodontitis.

\section{CONCLUSIONS}

The results of the present study indicate that $A$. actinomycetemcomitans is rare in native Brazilians with gingivitis but may be associated to gingival inflammation and periodontal breakdown in some patients with chronic periodontitis. All the isolates from patients with gingivitis and periodontitis were non-JP2 clones.

\section{ACKNOWLEDGEMENTS}

The authors thank Mrs Zulmira Alves de Souza and Christiane Marie Schweitzer for technical assistance. This study was supported by grant of Fundação do Amparo à Pesquisa do Estado de São Paulo (FAPESP) Proc. No. 07/ 51016-3.

\section{REFERENCES}

1- Botero JE, Contreras A, Lafaurie GI, Jaramillo A, Betancourt M, Arce RM. Occurrence of periodontopathic and superinfecting bacteria in chronic and aggressive periodontitis subjects in a Colombian population. J Periodontol. 2007;78:696-704.

2- Boutaga K, Savelkoul PHM, Winkel EG, Van Winkelhoff AJ. Comparison of subgingival bacterial sampling with oral lavage for detection and qualification of periodontal pathogens by real-time polymerase chain reaction. J Periodontol. 2007;78(1):79-86.

3- Bueno IC, Mayer MPA, DiRienzo JM. Relationship between conversion of localized juvenile periodontitis-susceptible children from health to disease and Actinobacillus actinomycetemcomitans leukotoxin promoter structure. J Periodontol. 1998;70:998-1007.

4- Colombo APV, Teles RP, Torres MC, Souto R, Rosalém W Jr, Mendes MCS, et al. Subgingival microbiota of Brazilian subjects with untreated chronic periodontitis. J Periodontol. 2002;73:360-9.

5- Cortelli JR, Cortelli SC, Jordan S, Haraszthy VI, Zambon JJ. Prevalence of periodontal pathogens in Brazilians with aggressive or chronic periodontitis. J Clin Periodontol. 2005;32:860-6.

6- Fine DH, Kaplan JB, Kachlany SC, Schreiner HC. How we got attached to Actinobacillus actinomycetemcomitans: a model for infectious diseases. Periodontol 2000. 2006;42:114-57.

7- Gaetti-Jardim E Jr, Bosco JMD, Lopes AM, Landucci LF, Gaetti-Jardim EC, Carneiro SRS. Occurrence of Actinobacillus actinomycetemcomitans in patients with chronic periodontitis, aggressive periodontitis, healthy subjects, and children with gingivitis in two cities of the State of São Paulo, Brazil. J Appl Oral Sci. 2006;14:153-6.

8- Haffajee AD, Bogren A, Hasturk H, Feres M, Lopez NJ, Socransky SS. Subgingival microbiota of chronic periodontits subjects from different geographic locations. J Clin Periodontol. 2004;31:996-1002.

9- Haubek D, Ennibi O-K, Poulsen K, Vaeth M, Poulsen S, Kilian M. Risk of aggressive periodontitis in adolescent carriers of the JP2 clone of Aggregatibacter (Actinobacillus) actinomycetemcomitans in Morocco: a prospective longitudinal cohort study. Lancet. 2008;371:237-42.

10- Herrera D, Contreras A, Gamonal J, Oteo A, Jaramillo A, Silva N, et al. Subgingival microbial profiles in chronic periodontitis patients from Chile, Colombia and Spain. J Clin Periodontol. 2008;35:106-13. 
11- Ide L, Lotufo RFM, Contreras A, Bergamaschi O, Slots J. Occurrence of seven putative periodontal pathogens in the subgingival plague of two native populations in Xingu Indian Park. Anaerobe. 2000;6:135-7.

12- Johansson A, Hänström L, Kalfas S. Inhibition of Actinobacillus actinomycetemcomitans leukotoxicity by bacteria from the subgingival flora. Oral Microbiol Immunol. 2000;15:218-25.

13- Kaplan JB, Schreiner HC, Furgang D, Fine DH. Population structure and genetic diversity of Actinobacillus actinomycetemcomitans strains isolated from localized juvenile periodontitis patients. J Clin Microbiol 2002;40:1181-7.

14- Kraig E, Dailey T, Kolodrubetz D. Nucleotide sequence of the leukotoxin gene from Actinobacillus actinomycetemcomitans: homology to the alpha-hemolysin/leukotoxin gene family. Infect Immun. 1990;58:920-9

15- Lafaurie GI, Contreras A, Barón A, Botero J, Mayorga-Fayad I, Jaramillo A, et al. Demographic, clinical, and microbial aspects of chronic and aggressive periodontitis in Colombia: a multicenter study. J Periodontol. 2007;78:629-39.

16- Lally ET, Hill RB, Kieba IR, Korostoff J. The interaction between RTX toxins and target cells. Trends Microbiol. 1999;7:357-61.

17- Leung WK, Ngai VKS, Yau JYY, Cheung BPK, Tsang, PWK, Corbet EF. Characterization of Actinobacillus actinomycetemcomitans isolated from young Chinese aggressive periodontitis patients. J Periodontal Res. 2005;40:258-68

18- Löe H, Silness J. Periodontal disease in pregnancy. I. Prevalence and severity. Acta Odontol Scand. 1963;21:533-51.

19- Lopez N, Socransky S, Da SI, Japlit M, Haffajee A. Subgingival microbiota of Chilean patients with chronic periodontitis. J Periodontol. 2004; $75: 717-25$

20- Messner AH, Lalakea ML, Aby J, Macmahon J, Bair E. Ankyloglossia Incidence and associated feeding difficulties. Arch Otolaryngol Head Neck Surg. 2000;126:36-9

21- Möller AJ. Microbial examination of root canals and periapical tissues of human teeth: methodological studies. Odontol Tidskr. 1966;74:1-138

22- Mombelli A, Gmür R, Lang NP, Corbet E, Frey F. Actinobacillus actinomycetemcomitans in Chinese adults. Serotype distribution and analysis of the leukotoxin gene promoter locus. J Clin Periodontol. 1999;26:505-10.

23- Nakano K, Inaba H, Nomura R, Nemoto H, Tamura K, Miyamoto E, et al. Detection and serotype distribution of Actinobacillus actinomycetemcomitans in cardiovascular specimens from Japanese patients. Oral Microbiol Immunol. 2007;22:136-9.

24- Rosalém W Jr, Souza RC, Andrade AFB, Colombo APV. Analysis of leukotoxin gene types of Actinobacillus actinomycetemcomitans in Brazilians with aggressive periodontitis. Braz J Microbiol. 2006;37:12734.

25- Silness J, Löe H. Periodontal disease in pregnancy II. Correlation between oral hygiene and periodontal condition. Acta Odontol Scand. $1964 ; 24: 747-59$

26- Slots J. Salient biochemical characteristic of Actinobacillus actinomycetemcomitans. Arch Microbiol. 1982:131:60-7.

27- Slots J. Selective medium for Actinobacillus actinomycetemcomitans. J Clin Microbiol. 1982;15:606-9.
28- Wu Y-M, Yan J, Chen L-L, Gu Z-Y. Association between infection of different strains of Porphyromonas gingivalis and Actinobacillus actinomycetemcomitans in subgingival plaque and clinical parameters in chronic periodontitis. J Zhejiang Univ Science B. 2007;8:121-31.

29- Ximenez-Fyvie LA, Almaguer-Flores A, Jacobo-Soto V, Lara-Cordoba M, Sanchez-Vargas LO, Alcantara-Maruri E. Description of the subgingival microbiota of periodontally untreated Mexican subjects: chronic periodontitis and periodontal health. J Periodontol. 2006;77:46071.

30- Yang H-W, Huang Y-F, Chan Y, Chou M-Y. Relationship of Actinobacillus actinomycetemcomitans serotypes to periodontal condition: prevalence and proportions in subgingival plaque. Eur J Oral Sci. 2005;113:28-33. 